\title{
Response of Different Levels of F Y M Vermicompost and Neem Cake on Soil Health Yield Attribute and Nutritional Value of Field Pea (Pisum sativum L.) var. Kashi Mukti
}

\author{
Mridul Srivastava*, Arun Alfred David, Narendra Swaroop and Tarence Thomas
}

Department of Soil Science and Agricultural Chemistry, Naini Agricultural Institute, Sam Higginbottom University of Agriculture, Technology and Sciences, Prayagraj 211007 U.P. India

*Corresponding author

\section{A B S T R A C T}

\begin{tabular}{|c|}
\hline Keywords \\
\hline $\begin{array}{l}\text { Field Pea, } \\
\text { Yield and FYM, } \\
\text { Vermicompost } \\
\text { and Neem cake }\end{array}$ \\
\hline Article Info \\
\hline $\begin{array}{l}\text { Accepted: } \\
18 \text { July } 2020 \\
\text { Available Online: } \\
10 \text { August } 2020\end{array}$ \\
\hline
\end{tabular}

A field experiment was conducted during the rabi season of 2019-20 at research farm of Soil Science and Agricultural Chemistry SHUATS, Prayagraj (U.P). Field trials were designed in split plot arrangement based on randomized block design with three replications and nine treatments. The treatment consisted of three factors namely farmyard Manure $(0,10, \& 20 \mathrm{~kg}$.), vermicompost $(0,1, \& 2 \mathrm{~kg}$.$) and neem Cake (0,0.25, \&$ $\left.0.5 \mathrm{t} \mathrm{ha}^{-1}\right)$. The result shows that application of different levels combination of farmyard manure, vermicompost and neem cake increased growth and yield of field pea. It was recorded from the application of bio-fertilizers in treatment $\mathrm{T}_{9}-\left[\begin{array}{ll}(@ 100 \% \text { farmyard } & \text { (10) }\end{array}\right.$ manure: vermicompost $+100 \%$ neem cake)] increased $\mathrm{pH} 7.44$, Electrical conductivity $0.23 \mathrm{dS} \mathrm{m} \mathrm{m}^{-1}$, organic carbon $0.69 \%$, available nitrogen $339.4 \mathrm{~kg} \mathrm{ha}^{-1}$, phosphorus $38.60 \mathrm{~kg}$ $\mathrm{ha}^{-1}$, potassium $206.35 \mathrm{~kg} \mathrm{ha}^{-1}$. The physical parameters of soil such as bulk density $\mathrm{mg} \mathrm{m}$ ${ }^{3}$, particle density $\mathrm{mg} \mathrm{m}^{-3}$, pore space $\%$ and solid space $\%$ increased. It was also concluded from trail that the application of fertilizers in treatment $\mathrm{T}_{9}-[(@ 100 \%$ farmyard manure: vermicompost $+100 \%$ neem cake)] was found in increased plant height, no. of leaves per plant, no. of branch, test weight $\left(\mathrm{g} \mathrm{plot}^{-1}\right)$ and grain yield and as well as yield.

\section{Introduction}

Pea (Pisum sativum L.) is a leguminous crop belonging to the family leguminoseae, which contain higher amount of protein and an excellent human food. Pea is mostly used in our diet throughout the world and it is rich inthe digestible protein (7.2 g), carbohydrates (15.8 g), Vitamin A (139 I.U.), Vitamin C (9 $\mathrm{mg}$ ), magnesium (34 $\mathrm{mg}$ ) and phosphorus
(139 mg) per $100 \mathrm{~g}$ of edible portion (Gopalkrishnan 2007) $^{[10]}$. Peas are very common nutritious vegetable and pulse crop. Several kinds of vegetables are grown in India, out of them vegetable pea is one of the foremost versatile legume crop, having much more protein than other vegetables. Two types of peas are generally cultivated - field pea (Pisum sativum L. var. arvense) generally used for 'dal' making and garden pea (Pisum 
sativum L. var. hortense) is a green coloured, wrinkled seeded, sweet in taste used as green vegetable. (Joshi et al., 2020). Vegetable pea is grown for their fresh green pods, for livestock forage and as soil enhancing green manure. Legumes, such as pea, are significant as it has the ability to fix atmospheric nitrogen through symbiotic nitrogen-fixing bacteria present in structures called root nodules. The nitrogen is one of the most important elements that cause intensive elongation growth of the main and lateral shoots (Tadeusz et al., 2013) ${ }^{[22]}$.Pea is a native of South West Asia and is widely grown in temperate countries like USA, China, France, Holland and Hungary. Pea thrives best in the cool climate with cardinal temperature range between $10^{\circ} \mathrm{C}$ to $30^{\circ} \mathrm{C}$. In India, it is grown as a winter vegetable in the plains of North India and as summer vegetable in the hills. Pea is grown in almost all types of soil with adequate drainage. Silt loam and clay loam soils having $\mathrm{pH}$ range of 5.5 to 6.5 are best for growing pea. India is the second largest producer of pea in the world. Pea occupies about 433.00 thousand hectares area which gives a total production of 39.61 lakh tonnes with 9.14t ha productivity (Anonymous, 2018).

In the country, pea is grown in Uttar Pradesh, Madhya Pradesh, Assam, Jharkhand, Himachal Pradesh, West Bengal, Punjab, Rajasthan, Haryana, Uttarakhand, Bihar etc. Cultivation of this crop is highly profitable and attractive to the farmers for its short durability. The garden pea is grown mainly for green pods and seeds are used as vegetables. The matured seeds can be used for preparing 'dal' or 'chapati' and other delicious foods. The progenitor of pea is unknown. Its cultivation maintains soil fertility through biological nitrogen fixation in association with symbiotic. Rhizobium prevalent in its root nodules and thus plays a vital role in fostering sustainable agriculture
(Negi et al., 2006). Therefore, apart from meeting its own requirement of nitrogen, peas are known to leave behind residual nitrogen in soil $50-60 \mathrm{~kg} \mathrm{ha}^{-1}$. It comes under the $3^{\text {rd }}$ number in protein content after garlic and beans. Pea is nutritious vegetable rich in protein, amino acid, carbohydrate and sugar. Pisum sativum L. is a rosid eudicot classified within the order Fabales (Bahadur et al., 2006). In order to meet out the nutritional demand of the increasing population, efforts are being made at the national and international level to increase the per hectare production.

Inorganic fertilizers mainly urea, SSP, MOP and different types of bulky organic manures such as, farmyard manure, compost and green manures and biofertilizers are normally used to increase soil productivity. There is a need to replace the high use of synthetic fertilizers by organic sources of nutrients to sustain soil health. Organic matter is considered as life of the soil, and also favours sustainable productivity (Baswana et al., 2007). So incorporation of plant residues particularly $\mathrm{N}_{2}$ - fixing legumes is a useful method to sustain organic matter content and thereby enhance the biological activity, improve soil fertility and increase nutrient availability to succeeding crop (Desuki et al., 2010).Biological $\mathrm{N}$ fixation can contribute over $80 \%$ of the $\mathrm{N}$ in pea plants and provide an average of $25 \mathrm{~kg} \mathrm{ha}^{-1}$ of $\mathrm{N}$ to the soil system for the succeeding crop (Indiresh et al., 2012).Fertilizers being vital agricultural inputs to increase the production but the main drawbacks in the use and manufacture of chemical fertilizers viz., energy crises and in availability of indigenous materials like naphtha, sulphur etc at the national level and hazardous effect of chemical fertilizers on our health and environment. All these things have led to the research of alternative renewable source of nutrients to the crop through fertilizers of biological origin (bio-fertilizers). 
All the biofertilizer are safe, low cost and easy in application. Biofertilizer application has shown bright results in case of leguminous crops, especially exclusive results have been obtained in case of pea. Biofertilizers are known to play an important role in increasing availability of nitrogen and phosphorus besides improving biological fixation of atmospheric nitrogen and enhance phosphorus availability to crop. Therefore, introduction of efficient strains of rhizobium in soils with low nitrogen may help augment nitrogen fixation and thereby boost production of crops. Phosphorus is known to play an important role in growth and development of the crop and have direct relation with root proliferations, straw strength, grain formation, crop maturation (Bhat et al., 2013). In order to maintain the nutrient balance in the soil for achieving optimum yield, integrated nutrient management practices are required. Use of organic acid and biofertilizers enhanced crop production and sustain soil health (Chopra et al., 2008).

The use of organic manure not only helps to sustain crop yield but also plays a key role by showing both direct as well as indirect influence on the nutrient availability in soil by improving the physical, chemical, and biological properties of soil and also improve the use efficiency of applied fertilizers (Das et al., 2015).Majority of studies have indicated that crop production has benefited from the application of organic residues due to the possibility of recycling organic matter, N, P and $\mathrm{K}$ and other nutrients (Ramana et al., 2011). Rather et al., (2010), reported that the use of soil amendment under a humid environment significantly increased the growth and yield of Pea pods. The soils of Prayagraj region are inherently fertile but soil origin disease is very common therefore a need for the application of external nutrient inputs in the form of neem Azadirachta indica seed cake for the growth of vegetables as well as other arable crops.

\section{Farmyard manure}

Sharma et al., (2011), mentioned that manure from cattle and other livestock is an important source of nutrients in the livestock-intensive regions. Farmyard manures are the major source of nutrient supply also on small farm holdings (Tarafdar et al., 2012). Manure has long been considered a desirable soil amendment, and reports of its effects on soil properties are numerous. Different animal manures have been used as a source of nutrients for crops cultivated.

As reported by (Smith et al., 2016), cattle manure comprised $80 \%$ of the total animal livestock manure production during the housing period, there at about $53 \%$ of this was estimated to be as solid, mainly straw-based cattle manure. In the intensive livestock farms with a limited area of agricultural land there is a risk of over-fertilizing with manure, which may result in increased nutrient leaching and groundwater contamination. Regular addition of organic materials, particularly the composted ones, increased soil physical fertility, mainly by improving aggregate stability and decreasing soil bulk density (Diacono et al., 2010).

The impact of animal manure depends on soil texture. According to (Dunjana et al., 2012), the addition of cattle manure resulted in significant $(\mathrm{P}<0.01)$ increases in soil organic carbon (SOC), macro-aggregate stability and aggregate protected carbon in clay soils. However, the addition of cattle manure on sandy soils, in contrast, increased significantly $(\mathrm{P}<0.05)$ only SOC but had no impact on soil bulk density and aggregate stability. Addition of animal manure may increase biodiversity in the soil, thereby causing alteration in composition, size, and 
activity of soil microorganisms and enzyme activities.

\section{Neem Cake}

Neem seed cake is the residual matter left after neem seed kernels are crushed to extract neem seed oil. Neem seed cake contains more nitrogen (2-5\%), phosphorus (0.5-1.0\%), potassium (1-2\%), calcium $(0.5-3 \%)$ and magnesium (0.3-1.0\%) than farmyard manure or sewage sludge. Neem seed cake not only provides nutrition to the plant, but increases the population of earthworms and produces organic acids, which helps in the reduction of soil alkalinity.

Eifediyi et al., (2010) asserted that neem seed cake acts as natural fertilizer with pesticide properties and neem seed cake exhibits insecticidal properties, nitrification retardation and inhibitor of pesticide degradation.Neem cake act as a nitrogen inhibitor means reduce the nitrification. It supplies the available nitrogen for a long time in the soil (Katyayan, 2012). Kumar et al., (2005), observed that neem seed cake increased the number of branches, root length and dry matter weight of crops after ten months compared to the control. There is therefore a need to reduce the use of inorganic fertilizers. Hence, the objective of the study was to evaluate the effects of neem seed cake on the soil properties as well as on growth and yield of Pea.

\section{Vermicompost}

Vermicomposting is an environmentally friendly technique that is used for organic solid waste management. Waste corn pulp blended with cow dung and office paper was vermicomposted over 30 days to produce vermicompost which is a solid bio with peas at the planting phase and after every four weeks.
The impact of vermicompost on the soil was quantified. Application of vermicompost resulted in a $33 \%, 40 \%$, and $67 \%$ increase in the soil nitrogen potassium content respectively. Furthermore, Zinc, copper, manganese and iron indicated a 91\%, 67\%, $56 \%$ and $10 \%$ increase in nutrient composition.

The peas showed vigor and vitality during the period of growth. Vermicompost can be used for sustainable agriculture practices easing food shortages hence improved food security. Pea can be grown on a variety of soil from light sandy loan to clay through best result results are obtained on well drained, loose friable loamy soil. The $\mathrm{pH}$ range falls in between 6.0 and 7.5 (Anonymous, 2018).

\section{Materials and Methods}

The experiment was conducted during the cumulative period, beginning from rabi season 2019-20 at research farm of Soil Science and Agricultural Chemistry, Sam Higginbottom University of Agriculture, Technology and Sciences, and is situated $5 \mathrm{~km}$ away on the right bank of Yamuna river, Prayagraj (Allahabad) district of Uttar Pradesh. Prayagraj which is located at $25^{\circ} 58^{\prime}$ north latitude and $81^{0} 52$ 'east longitude, lies on $102 \mathrm{~m}$ above sea level having warm and temperate climate.

In winter, there is much more rainfall in Prayagraj than in summer. The average annual temperature of Prayagraj is $25.7{ }^{\circ} \mathrm{C}$ and annual rainfall is $981 \mathrm{~mm}$ (Climate data.org).Pea is most commonly the soil spherical seed or the seed-pot of the pod fruit. Pea is an annual plant with a life cycle of one year. It is a cool season crop grown in many parts of the world. The soil of experimental area falls in order of Inceptisol and in experimental plots is alluvial soil in nature. 
The soil samples randomly collect from five different sites in the experiment plot prior to tillage operation from a depth of $0-15 \mathrm{~cm}$. The size of the soil sample reduces by conning and quartering the composites soil sample is air dry and pass through a $2 \mathrm{~mm}$ sieve by way of preparing the sample for physical and chemical analysis.

\section{Pre-harvest observations recorded during growth stages}

\section{Plant height (cm)}

Five plants were randomly selected from each plot except border rows, tagged permanently and used for measurement of plant height. Height of each tagged plant was measured at 15,3045 and 60 days after sowing from ground to the tip of the plant by meter scale in centimeter and average of five plants was computed as mean plant height $(\mathrm{cm})$.

\section{Number of leaves per plant ${ }^{-1}$}

The number of fresh green leaves per plant of field pea was counted at different stages of the crop growth from the selected tagged plants per plot and mean of observation of five plants were computed.

\section{Number of branches per plant ${ }^{-1}$}

Number of branches of five tagged plants from each plot was counted and average number of branches per plant was calculated at $15,30,45$ and 60 days.

\section{No. of pods per plant ${ }^{-1}$}

The randomly selected already tagged plants were used for counting number of pods per plant and average was worked out or total number of pods on the tagged plants was counted and average number of pods plant ${ }^{-1}$ was recorded.

\section{Post-harvest observations recorded during growth stages}

\section{Fresh Weight per plant (g)}

Three plants from each plot were randomly taken and weighed at 80 DAS.

\section{Pods yield (q ha $\left.{ }^{-1}\right)$}

The pods yield from the net plot area was recorded in $\mathrm{kg} \mathrm{plot}^{-1}$ and value converted into $\mathrm{q} \mathrm{ha}{ }^{-1}$.

\section{Dry weight per plant}

Three uprooted plants kept in over for $24 \mathrm{hrs}$. at 60 degree celcius at maintain and dry weight was calculated as average dry weight per plant was calculated.

\section{Harvest index (\%)}

The harvest index was calculated by using the formula given by Nichiporovich (1995)

$$
\text { Harvest Index }=\frac{\text { Biological Yield }}{\text { Economical Yield }}
$$

\section{pH}

The $\mathrm{pH}$ of soil was determined in 1:2.5 soil water suspensions. The buffer standard of known $\mathrm{pH}$ values of 4.0, 7.0 and 9.2 at 250 was maintained. By stirring the samples intermittently for 30 minutes, reading was recorded using a digital $\mathrm{pH}$ meter.

\section{Electrical conductivity $\left(\mathrm{dS} \mathrm{m}^{-1}\right)$}

Electrical conductivity of the soil was determined in the supernatant of 1:2.5 soil water suspension that kept for stirring constantly for 30 minutes, reading was noted by using digital Electrical conductivity meter. 


\section{Organic carbon $\left(\mathrm{kg} \mathrm{ha}^{-1}\right)$}

Initially $2 \mathrm{~mm}$ sieved soil sample was ground in agate pestle and mortar and passed through $0.5 \mathrm{~mm}$ sieve. Later organic carbon content of the soil was estimated by wet oxidation method.

\section{Available nitrogen $\left(\mathrm{kg} \mathrm{ha}^{-1}\right)$}

Here, modified alkaline permanganate oxidation method was used in estimating available nitrogen. The organic matter present in the soil was oxidized by the nascent oxygen liberated by $\mathrm{KMnO}_{4}$ in the presence of $\mathrm{NaOH}$ and quantity of $\mathrm{NH}_{3}$ distilled was estimated by titrating against a standard $\mathrm{H}_{2} \mathrm{SO}_{4}$

\section{Available phosphorus $\left(\mathrm{kg} \mathrm{ha}^{-1}\right)$}

Available phosphorus in soil was determined by the $0.5 \mathrm{M}$ sodium bicarbonate method (Olsen's extractant) and stannous chloride, which was used for development of blue color. Soil in presence of added extractant shaking has done for 30 minutes, filtered, and treated with ammonium molybdate (complexing agent). The intensity of blue colour was read using spectrophotometer at $660 \mathrm{~nm}$ wave.

\section{Available potassium (kg ha $\left.{ }^{-1}\right)$}

Determination of available potassium, accomplished with potassium extraction by using neutral normal ammonium acetate $(\mathrm{pH}$ 7.0) which acts as extractant and the contentof potassium in the extractant were obtained using flame photometer.

\section{Results and Discussion}

Plant height increased with the successive addition of farmyard manure, Vermicompost and neem cake. Highest plant height at 15 DAS $(6.01 \mathrm{~cm}), 30$ DAS $(13.05 \mathrm{~cm}), 45$ DAS
$(33.82 \mathrm{~cm})$, and 60 DAS $(61.05 \mathrm{~cm})$ was recorded with integrated application of $\mathrm{T}_{9 \text { - }}$ $(100 \%$ Neem Cake $+100 \%$ Farmyard manure: Vermicompost). Maximum number of branches with mean at 15 DAS (2.55), 30 DAS (4.88), 45 DAS (7.23), 60 DAS (11.67), was also obtained with $\mathrm{T}_{9}-(100 \%$ Farmyard manure: Vermicompost $+100 \%$ Neem Cake). Maximum number of leaves with mean at 15 DAS (5.34), 30 DAS (22.94), 45 DAS (34.14), 60 DAS (58.07), was also obtained with $\mathrm{T}_{9}-(100 \%$ Farmyard manure: Vermicompost $+100 \%$ Neem Cake). Fresh weight per plant after harvest was recorded to be highest in $\mathrm{T}_{9-}-(100 \%$ Farmyard manure: Vermicompost + Neem Cake) (25.40g) and minimum in control $\mathrm{T}_{1-}(0 \%$ Farmyard manure: Vermicompost $+0 \%$ Neem Cake) (14.36gm.). Dry weight was recorded to be highest in $\mathrm{T}_{9}-(100 \%$ Farmyard manure: Vermicompost $+100 \%$ Neem Cake) (10.66 gm.) and lowest in $\mathrm{T}_{1}-(0 \%$ Farmyard manure: vermicompost + Neem Cake) $(6.48 \mathrm{gm})$. The test weight was significantly higher in $\mathrm{T}_{9^{-}}$ (100\% Farmyard manure: Vermicompost + $100 \%$ Neem Cake) (40.58) and lowest in $\mathrm{T}_{1}$ (0\% Farmyard manure Vermicompost $+0 \%$ Neem Cake) (34.88). The pod yield was also recorded higher with $\mathrm{T}_{9}-(100 \%$ Farmyard manure: Vermicompost $+100 \%$ Neem Cake (78.65kg.). The maximum $\mathrm{pH} 7.44$ was recorded with $\mathrm{T}_{9-}(100 \%$ Farmyard manure: Vermicompost $+100 \%$ Neem Cake) treatment combination followed by 7.06 with $\mathrm{T}_{5}-(100 \%$ Farmyard manure: Vermicompost $+50 \%$ Neem Cake) treatment whereas the minimum $6.56 \mathrm{pH}$ was recorded with control $\mathrm{T}_{1}-(0 \%$ Farmyard manure: Vermicompost + $0 \%$ Neem) Cake treatment. The trend of Electrical Conductivity the maximum EC dS $\mathrm{m}^{-1} \quad 0.29$ was recorded with $\mathrm{T}_{4}-(100 \%$ Farmyard manure: Vermicompost $+50 \%$ Neem Cake) treatment combination followed by 0.28 with $\mathrm{T}_{5}-(100 \%$ Farmyard manure: Vermicompost $+50 \%$ Neem Cake) treatment whereas the minimum $0.20 \mathrm{EC}$ was recorded 
with control $\mathrm{T}_{1}-(0 \%$ Farmyard manure: Vermicompost $+0 \%$ Neem Cake) non difference in EC interaction between Farmyard manure, Vermicompost and Neem Cake.The result of the data depicted that the maximum organic carbon $0.69 \%$ was recorded with $\mathrm{T}_{9}-(100 \%$ Farmyard manure: Vermicompost $+100 \%$ Neem Cake) treatment combination followed by $0.66 \%$ with $\mathrm{T}_{5}$ treatment whereas the minimum 0.34 organic carbon was recorded with control $\mathrm{T}_{1}$ treatment. The statistical analysis of organic carbon data indicates that there was nonsignificant difference in organic carbon interaction between Farmyard manure, Vermicompost and Neem Cake. In case of available nitrogen the maximum available nitrogen $339.40\left(\mathrm{~kg} \mathrm{ha}^{-1}\right)$ was recorded with $\mathrm{T}_{9}-(100 \%$ Farmyard manure: Vermicompost $+100 \%$ Neem Cake) treatment combination followed by $336.98\left(\mathrm{~kg} \mathrm{ha}^{-1}\right)$ with $\mathrm{T}_{5}-(100 \%$ Farmyard manure: Vermicompost $+50 \%$ Neem Cake) treatment combination whereas the minimum $314.32\left(\mathrm{~kg} \mathrm{ha}^{-1}\right)$ available nitrogen was recorded with control $\mathrm{T}_{1}-(0 \%$ Farmyard manure: Vermicompost $+0 \%$ Neem Cake) treatment (Fig. 1 and 2; Table 1$5)$.

\section{Table.1 Treatment Combination of Field Pea}

\begin{tabular}{|c|c|}
\hline Treatment & Treatment combination \\
\hline$T_{1}\left(\mathbf{F}_{0} \mathbf{N}_{0} \mathbf{V}_{0}\right)$ & @0\% (FYM )+@0\% Neemcake+ @0\% vermicompost \\
\hline $\mathbf{T}_{2-(}\left(\mathbf{F}_{1} \mathbf{N}_{2} \mathbf{V}_{2}\right)$ & @0\% (FYM ) + @ 50\% Neemcake+ @50\% vermicompost \\
\hline$T_{3}\left(\mathbf{F}_{1} \mathbf{N}_{3} \mathbf{V}_{3}\right)$ & @0\% (FYM)+@100\% Neemcake + @ 100\% vermicompost \\
\hline $\mathbf{T}_{4}\left(\mathbf{F}_{2} \mathbf{N}_{1} \mathbf{V}_{1}\right)$ & @50\% (FYM ) + @0\% Neemcake +@0\% vermicompost \\
\hline $\mathbf{T}_{5}\left(\mathbf{F}_{2} \mathbf{N}_{2} \mathbf{V}_{2}\right)$ & @50\% (FYM )+@ $50 \%$ Neemcake+ @50\% vermicompost \\
\hline$T_{6}-\left(F_{2} N_{3} V_{3}\right)$ & @50\%(FYM)+@100\% Neemcake+ @ 100\% vermicompost \\
\hline $\mathbf{T}_{7}\left(\mathbf{F}_{3} \mathbf{N}_{1} \mathbf{V}_{1}\right)$ & @100\% (FYM )+@0\% Neemcake + @0\% vermicompost \\
\hline $\mathbf{T}_{8}-\left(\mathbf{F}_{3} \mathbf{N}_{2} \mathbf{V}_{2}\right)$ & @ 100\%(FYM)+ @ 50\% Neemcake+ @50\% vermicompost \\
\hline $\mathbf{T}_{9}\left(\mathbf{F}_{3} \mathbf{N}_{3} \mathbf{V}_{3}\right)$ & @100\%(FYM)+ @ 100\%Neemcake +@ 100\% vermicompost \\
\hline
\end{tabular}

Table.2 Mechanical analysis of pre experimental soil

\begin{tabular}{|l|c|l|}
\hline \multicolumn{1}{|c|}{ Particulars } & Results & \multicolumn{1}{c|}{ Method employed } \\
\hline Sand (\%) & 70.4 & Bouyoucos Hydrometer \\
Bouyoucos (1927)
\end{tabular}


Table.3 Chemical analysis of pre experimental soil

\begin{tabular}{|l|l|c|}
\hline Parameters & Method employed & Results \\
\hline Soil pH (1:2) & Digital pH meter (Jackson, 1958) & 7.85 \\
\hline Soil EC(dSm $\mathbf{- 1})$ & Digital EC meter (Wilcox, 1950) & 0.44 \\
\hline Organic Carbon (\%) & Wet Oxidation Method (Walkley and Black 1934) & 0.41 \\
\hline Available Nitrogen $\left(\mathbf{k g h a}^{-\mathbf{1}}\right)$ & Kjeldhal Method (Subbaih and Asija, 1956) & 210.35 \\
\hline Available Phosphorus $\left(\mathbf{k g h a}^{-\mathbf{1}}\right)$ & Colorimetric method (Olsen et al., 1954) & 20.00 \\
\hline Available Potassium $\left(\right.$ kgha $\left.^{-\mathbf{1}}\right)$ & Flame photometric method (Toth and Prince, 1949) & 240.90 \\
\hline
\end{tabular}

Table.4 Effect of FYM, Vermicompost and Neem Cake on physio-chemical properties of Field Pea var. Kashi Mukti

\begin{tabular}{|c|c|c|c|c|c|c|c|c|c|c|}
\hline Treatment & $\begin{array}{c}\text { Bulk } \\
\text { Densiy }\end{array}$ & $\begin{array}{l}\text { Partice } \\
\text { density }\end{array}$ & $\begin{array}{c}\text { Pore } \\
\text { Space } \\
(\%)\end{array}$ & $\begin{array}{c}\text { Solid } \\
\text { Space } \\
(\%)\end{array}$ & $\begin{array}{c}\text { Soil } \\
\text { pH }\end{array}$ & $\underset{\left(\mathbf{d S m}^{-1}\right)}{\mathbf{E C}}$ & $\begin{array}{c}\text { Organic } \\
\text { Carbon } \\
(\%)\end{array}$ & $\begin{array}{c}\mathrm{N} \\
\left(\mathrm{kg} \mathrm{ha}^{-1}\right)\end{array}$ & $\begin{array}{c}P \\
\left(\mathrm{~kg} \mathrm{ha}^{-1}\right)\end{array}$ & $\begin{array}{c}\mathrm{K} \\
\left(\mathrm{kg} \mathrm{ha}^{-1}\right)\end{array}$ \\
\hline$T_{1}$ & 1.05 & 2.24 & 42.44 & 52.23 & 6.56 & 0.24 & 0.34 & 314.32 & 24.96 & 178.4 \\
\hline $\mathbf{T}_{2}$ & 1.06 & 2.26 & 47.49 & 52.82 & 6.66 & 0.23 & 0.39 & 320.45 & 26.80 & 183.8 \\
\hline $\mathbf{T}_{3}$ & 1.07 & 2.52 & 42.28 & 55.22 & 6.77 & 0.21 & 0.45 & 328.56 & 27.65 & 195.8 \\
\hline$T_{4}$ & 1.03 & 2.20 & 41.40 & 54.20 & 6.74 & 0.29 & 0.42 & 326.40 & 29.63 & 195.23 \\
\hline$T_{5}$ & 1.09 & 2.40 & 41.60 & 58.59 & 7.06 & 0.28 & 0.66 & 336.98 & 32.40 & 203.73 \\
\hline$T_{6}$ & 1.08 & 2.85 & 45.42 & 57.00 & 6.89 & 0.25 & 0.48 & 334.12 & 31.70 & 199.25 \\
\hline $\mathbf{T}_{7}$ & 1.05 & 2.32 & 45.77 & 57.32 & 6.95 & 0.23 & 0.53 & 335.60 & 31.80 & 203.56 \\
\hline$T_{8}$ & 1.06 & 2.56 & 45.32 & 58.90 & 6.88 & 0.24 & 0.44 & 330.06 & 31.50 & 199.03 \\
\hline$T_{9}$ & 1.07 & 2.45 & 45.86 & 56.18 & 7.44 & 0.23 & 0.69 & 339.40 & 38.60 & 206.35 \\
\hline F- test & NS & NS & NS & NS & NS & NS & $S$ & $\mathrm{~S}$ & NS & $\mathrm{S}$ \\
\hline S.Ed ( \pm$)$ & 0.068 & 0.256 & 4.253 & 4.325 & 0.235 & 0.054 & 0.0009 & 1.89 & 38.522 & 0.78 \\
\hline C.D. at 5\% & 0.081 & 0.325 & 8.365 & 10.365 & 0.227 & 0.058 & 0.018 & 2.255 & 80.65 & 1.65 \\
\hline
\end{tabular}

Table.5 Effect of FYM, Vermicompost and Neem Cake on growth and yield parameters of Field Pea var. Kashi Mukti

\begin{tabular}{|c|c|c|c|c|c|c|c|}
\hline Treatment & $\begin{array}{l}\text { Plant } \\
(\mathbf{c m})\end{array}$ & $\begin{array}{l}\text { Branches } \\
\text { Plant }^{-1}\end{array}$ & $\begin{array}{l}\text { Leaves } \\
\text { Plant }^{-1}\end{array}$ & $\begin{array}{l}\text { FreshWeight } \\
\text { (g plant }^{-1} \text { ) }\end{array}$ & $\begin{array}{l}\text { Dry weight } \\
\left(\mathrm{g} \mathrm{plant}^{-1}\right)\end{array}$ & $\begin{array}{l}\text { Test weight } \\
\text { (g) }\end{array}$ & $\begin{array}{l}\text { Yield } \\
\left(q_{\text {ha }}^{-1}\right)\end{array}$ \\
\hline$T_{1}$ & 39.56 & 09.88 & 49.40 & 15.26 & 6.48 & 34.88 & 26.79 \\
\hline $\mathbf{T}_{2}$ & 44.87 & 10.82 & 52.66 & 14.36 & 7.88 & 35.45 & 59.84 \\
\hline $\mathbf{T}_{3}$ & 46.54 & 11.29 & 55.20 & 19.00 & 8.30 & 36.45 & 60.10 \\
\hline $\mathbf{T}_{4}$ & 46.40 & 11.25 & 54.54 & 18.24 & 8.25 & 35.48 & 52.55 \\
\hline$T_{5}$ & 57.87 & 11.56 & 59.87 & 23.84 & 9.40 & 39.04 & 77.65 \\
\hline$T_{6}$ & 51.34 & 11.42 & 55.74 & 19.28 & 8.50 & 37.34 & 65.23 \\
\hline $\mathbf{T}_{7}$ & 51.80 & 11.50 & 59.00 & 19.52 & 8.56 & 37.88 & 68.00 \\
\hline$T_{8}$ & 50.70 & 11.40 & 55.27 & 19.14 & 8.34 & 36.48 & 64.47 \\
\hline$T_{9}$ & 61.05 & 11.67 & 63.00 & 26.12 & 10.66 & 40.58 & 78.65 \\
\hline F- test & $\mathrm{S}$ & $\mathrm{S}$ & $\mathrm{S}$ & $\mathrm{S}$ & $\mathrm{S}$ & $\mathrm{S}$ & $\mathrm{S}$ \\
\hline S.Ed. ( \pm$)$ & 2.44 & 0.418 & 1.927 & 1.171 & 0.721 & 0.671 & 1.56 \\
\hline C.D. at 5\% & 5.45 & 0.254 & 2.36 & 2.478 & 1.289 & 1.225 & 0.28 \\
\hline
\end{tabular}


Fig.1 Impact of Different levels of FYM, Vermicompost and Neem Cake on their interaction N P K of Field Pea var. Kashi Mukti

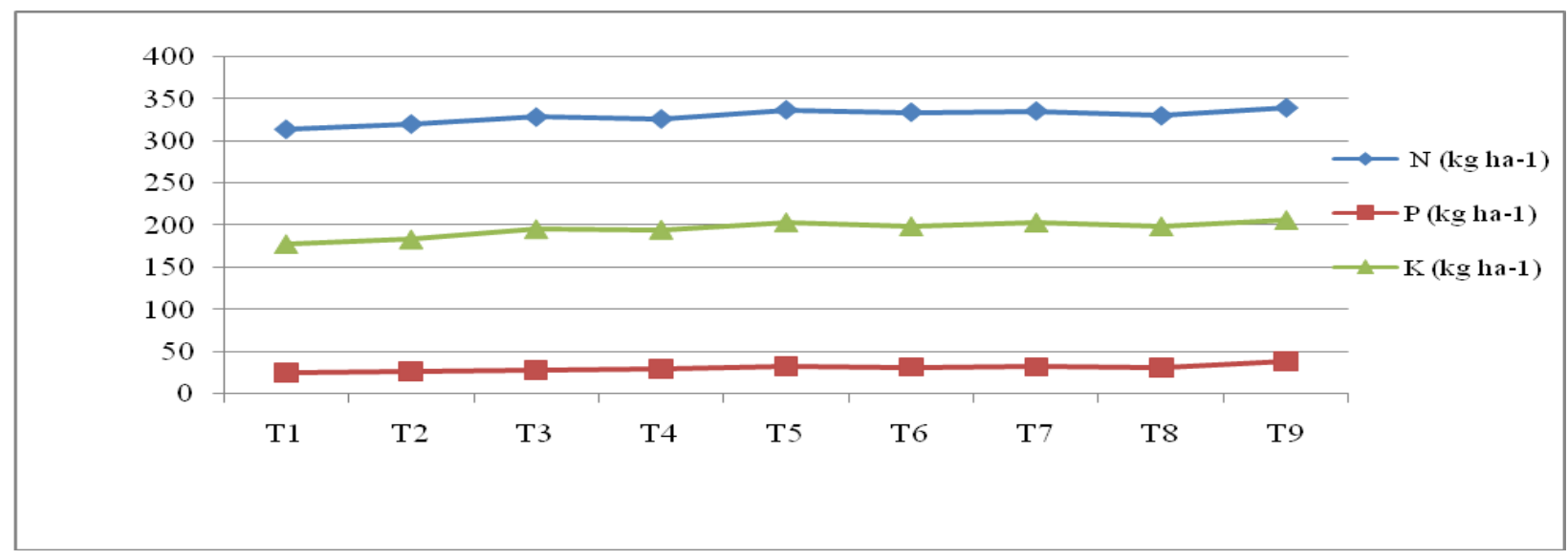

Fig.2 Impact of Different levels of FYM, Vermicompost and Neem Cake on their interaction on $\mathrm{pH}, \mathrm{EC}$ and organic carbon of Field Pea var. Kashi Mukti

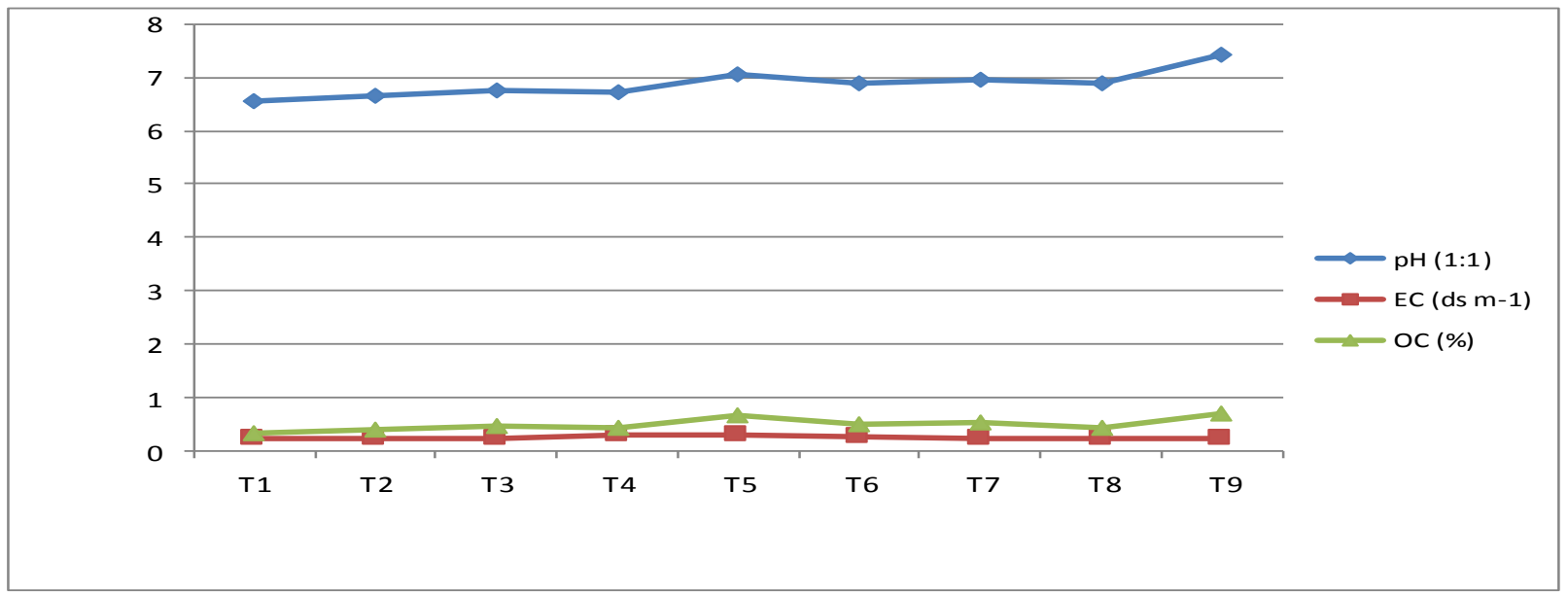

The maximum available phosphorus $38.6(\mathrm{~kg}$ ha-1) was recorded with T9-(100\% Farmyard manure: Vermicompost $+100 \%$ Neem Cake) treatment combination followed by $32.4(\mathrm{~kg}$ ha-1) with T5-(100\% Farmyard manure: Vermicompost $+100 \%$ Neem Cake) treatment combination whereas the minimum 24.96 (kg ha-1) available phosphorus was recorded with control T1-(0\% Farmyard manure: Vermicompost $+0 \%$ Neem Cake) treatment. The statistical analysis of available phosphorus data indicates that there was significant difference in available phosphorus interaction between Farmyard manure, vermicompost and neem cake. The maximum potassium $206.35\left(\mathrm{~kg} \mathrm{ha}^{-1}\right)$ was recorded with $\mathrm{T}_{9}-(100 \%$ Farmyard manure: vermicompost + $100 \%$ neem cake) treatment combination followed by $203.73\left(\mathrm{~kg} \mathrm{ha}^{-1}\right)$ with $\mathrm{T}_{5}-(100 \%$ Farmyard manure: vermicompost $+50 \%$ neem cake) treatment combination whereas the minimum $178.4\left(\mathrm{~kg} \mathrm{ha}^{-1}\right)$ potassium was recorded with control $\mathrm{T}_{1^{-}}(0 \%$ Farmyard manure: vermicompost $+0 \%$ neem cake) treatment. The statistical analysis of potassium data indicates that there was 
significant difference in potassium interaction between Farmyard manure, Vermicompost and Neemcake.

It was concluded that ttreatment $\mathrm{T}_{9}-[(@ 100 \%$ FYM:Vermicompost $+100 \%$ Neem Cake)] is best for growth and yield attributes of Field Pea var. Kashi Muktiin comparison to other treatment combination. It was recorded from the application of Biofertilizers for research investigation, delivered to Field Pea, for optimum yield requirement for farmers livelihood, the best alternative way to sound success in agriculture production is by effective utilization of higher organic resource as treatment $\mathrm{T}_{9^{-}} \quad[(@ 100 \%$ FYM: Vermicompost $+100 \%$ Neem Cake)]. This was found to be the best treatment and highest benefit of ₹ 58651with highest cost benefit ratio. It could be recommended for profitable production of Field Pea var. Kashi Mukt iand maintain soil physical and chemical properties.

\section{Acknowledgement}

I am grateful for ever-inspiring guidance, constant encouragement, keen interest and scholarly comments and constructive suggestions throughout the course of my studies and investigation from Head of the department and staff, Department of Soil Science and Agricultural Chemistry, Sam Higginbottom University of Agriculture, Technology and Sciences, Prayagraj, Uttar Pradesh.

\section{References}

Bhat AT, Gupta M, Ganai MA, Ahanger AR, Bhat AH. Yield, soil health and nutrient utilization of ield pea (Pisum sativum L.) as affected by phosphorus and biofertilizers under subtropical conditions of Jammu. International Journal of Modern Plant and Animal Sciences 2013; 1(1):1-8.
Bouyoucous GJ. the hydrometer as a new method for the mechanical analysis of soils. Soil Sci. 1927; 23:393-395.

Bahadur A, Singh J, Singh KP, Mathura R. Effect of plant growth, yield and quality attributes of garden pea as influenced by organic amendments and biofertilizers. Indian Journal of Horticultural. 2006; 63(4):464-466.

Baswana KS, Rana MK. Effect of organic sources and bio-fertilizers on growth and yield of garden pea (Pisum sativum L.) Haryana Journal of Horticultural Science. 2007; 36(3-4):326-330.

Chopra S, Sharma JP, Kumar K. Influence of integrated nutrient management on growth, yield and quality of vegetable pea. Journal of Plant Science Research. 2008; 24(2):199-202.

Chopra SL, Kunwar JS. Analytical Agriculture Chemistry Kalyani Pulications, New Delhi, 1974, 54.

Das D, Dwivedi BS, Meena MC. Integrated nutrient management for improving soil health and crop productivity. Indian J. Fert. 2015;11(4):64-83.

Diacono, Mariangela and Montemurro, Francesco. Effectiveness of Organic Wastes as Fertilizers and Amendments in Salt-Affected Soils. Agriculture. 2015; (5) 221-230.

Dunjana, Nothando and Nyamugafata, P. and Armwell, Shumba and Nyamangara, Justice and Zingore, Shamie. Effects of cattle manure on selected soil physical properties of smallholder farms on two soils of Murewa, Zimbabwe. Soil Use and Management. 2012; 28(10):14752743.

El-Desuki MH, Magda MM, Asmaa R, Abd ElAl FS. Effect of organic and biofertilizers on the plant growth, green pod yield and quality of pea, International Journal of Academic Research. 2010; 2(1):111-113.

Eifediyi, Kevin and Remison, S. Growth and yield of cucumber (Cucumis sativus L.) as influenced by farmyard manure and inorganic fertilizer. Journal of Plant 
Breeding and Crop Science. 2010; (2): 216-220.

Gopalkrishnan TR. Vegetable crops. New India publishing agency, New Delhi. 2007; 4:170.

Indiresh KM, Patil AB, Lingaiah HB, Santhosha HM, Anjanappa M. Demonstration of the scope and feasibility of organic farming in vegetable crops - an experience. Seaveg, Regional Symposium, 24-26 January, 2012; 176-180.

Jaipal, Sharma S, Dixit AK, Sharma AK. Growth and yield of capsicum and garden pea as influenced by organic manures and biofertilizers, Indian. Journal of Agricultural Sciences 2011; 81(7):637-642.

Joshi H N, Varma L R and More SR Effects of organic nutrients in combination with biofertilizers on uptake $\mathrm{N}, \mathrm{P}, \mathrm{K}$ and yield of garden pea (Pisum sativum L.) The Pharma Innovation Journal 2020; 9(3): 385-389.

Negi S, sing RV, Dewivdi OK. Effect of Biofertilizers, nutrient and lime on growth and yield of garden pea, Legume research. 2006; 29(4):282-285.

Ramana V, Ramakrishna PK, Balakrishna RK. Effect of bio-fertilizers on growth, yield and quality of French bean (Phaseolus vulgaris). Vegetable Science. 2011; 38(1):35-38.

Rather SA, Hussain MA, Sharma NL. Effect of biofertilizers on growth, yield and economics of field pea. International Journal of Agricultural Sciences. 2010; 6(1):65-66.
Sandeep Kumar, Seema Dhankhar, Ved Priya Arya, Sanjay Yadav and J. P. Yadav Antimicrobial activity of Salvadora oleoides Decne. against some microorganisms Journal of Medicinal Plants Research Vol. 6(14), 2012; (1): 2754-2760.

Sharma U, Chauhan JK. Influence of integrated use of inorganic and organic sources of nutrients on growth and production of pea. Journal of Farm Sciences. 2011; 1(1):14-18.

Smith, K.A. and Williams, Adrian. Production and management of cattle manure in the UK and implications for land application practice. Soil Use and Management 2016; 32(2): 73-82.

Tadeusz Z, Agnieszk KK, Oleksy A. Effect of Rhizobium inoculation of seeds and foliar fertilization on productivity of Pisum sativum L. Acta Agrobotanica. 2013; 66(2):71-78.

Tarafdar JC, Rao AV. Response of clusterbean to Glomus mosseae and Rhizobium in arid soil fertilized with nitrogen, phosphorus and farm yard manure. Journal of the Indian Society of Soil Science. 2001; 49(1):751-755.

Weisany W, Raei Y, Allahverdipoor KH. Role of Some of Mineral Nutrients in Biological Nitrogen Fixation. Bulletin of Environment, Pharmacology and Life Sciences. 2013; 2(4):77-84.

Yadav VS, Luthra JP. Effect of organic manures at different levels of phosphorus on yield and economics of vegetable pea. Journal of Horticultural Sciences. 2005; 11(2):120-122.

\section{How to cite this article:}

Mridul Srivastava, Arun Alfred David, Narendra Swaroop and Tarence Thomas. 2020. Response of Different Levels of F Y M Vermicompost and Neem Cake on Soil Health Yield Attribute and Nutritional Value of Field Pea (Pisum sativum L.) var. Kashi Mukti. Int.J.Curr.Microbiol.App.Sci. 9(08): 1679-1689. doi: https://doi.org/10.20546/ijcmas.2020.908.193 